\title{
Response of Sex Steroid Hormone Synthesis Substrates in Serum and Testes of Male Tilapia (Oreochromis niloticus) Exposed to Methomyl and Its Recovery Pattern
}

\author{
Shunlong Meng ${ }^{1,2,+}{ }^{\oplus}, X_{i}$ Chen ${ }^{1,2,+}$, Chao Song ${ }^{1}$, Limin Fan ${ }^{1}$, Liping Qiu ${ }^{1}$, Gengdong Hu ${ }^{1}$, Jiazhang Chen ${ }^{1,2, *}$ \\ and Pao Xu ${ }^{1,2, *}$ \\ 1 Freshwater Fisheries Research Center, Chinese Academy of Fishery Sciences, Scientific Observing and \\ Experimental Station of Fishery Resources and Environment in the Lower Reaches of the Changjiang River, \\ Wuxi 214081, China; mengsl@ffrc.cn (S.M.); chenx@ffrc.cn (X.C.); songc@ffrc.cn (C.S.); fanlm@ffrc.cn (L.F.); \\ qiulp@ffrc.cn (L.Q.); hugd@ffrc.cn (G.H.) \\ 2 Wuxi Fishery College, Nanjing Agricultural University, Wuxi 214081, China \\ * Correspondence: chenjz@ffrc.cn (J.C.); xup@ffrc.cn (P.X.); Tel.: +86-510-85551443 (J.C.); +86-510-85557959 (P.X.); \\ Fax: +86-510-85551443 (J.C.) \\ + Shunlong Meng and $\mathrm{Xi}_{\mathrm{i}}$ Chen contributed equally to this paper.
}

\section{check for} updates

Citation: Meng, S.; Chen, X.; Song, C.; Fan, L.; Qiu, L.; Hu, G.; Chen, J.; Xu, P. Response of Sex Steroid Hormone Synthesis Substrates in Serum and Testes of Male Tilapia (Oreochromis niloticus) Exposed to Methomyl and Its Recovery Pattern. Appl. Sci. 2021, 11, 10997. https://doi.org/10.3390/ app112210997

Academic Editor: Vera Lúcia Maria

Received: 6 September 2021

Accepted: 12 November 2021

Published: 20 November 2021

Publisher's Note: MDPI stays neutral with regard to jurisdictional claims in published maps and institutional affiliations.

Copyright: (c) 2021 by the authors. Licensee MDPI, Basel, Switzerland. This article is an open access article distributed under the terms and conditions of the Creative Commons Attribution (CC BY) license (https:/ / creativecommons.org/licenses/by/ $4.0 /)$.
Abstract: The response of synthetic substrates of sex steroid hormones - cholesterol ( $\mathrm{CHO})$, pregnenolone (PREG), and progesterone (PROG) — in the serum and testes of male tilapia (Oreochromis niloticus) to the environmental estrogen pesticide methomyl $\left(0.2,2,20\right.$, and $\left.200 \mu \mathrm{g} \cdot \mathrm{L}^{-1}\right)$ was evaluated using staticwater contact toxicity tests. The results showed that low methomyl concentrations $\left(0.2\right.$ and $\left.2 \mu \mathrm{g} \cdot \mathrm{L}^{-1}\right)$ had no significant effects on the contents of CHO, PREG, and PROG in the serum and testes of male tilapia $(p>0.05)$. Consequently, the concentration of $2 \mu \mathrm{g} \cdot \mathrm{L}^{-1}$ could be used as a preliminary reference threshold for the non-effective dose of methomyl in male tilapia. Exposure to high methomyl concentrations (20 and $200 \mu \mathrm{g} \cdot \mathrm{L}^{-1}$ ) significantly inhibited the levels of CHO, PREG, and PROG in the serum and testes of male tilapia $(p<0.05)$ and showed a dose-response relationship. Sex steroid hormone synthesis substrate damage to male tilapia caused by less than $20 \mu \mathrm{g} \cdot \mathrm{L}^{-1}$ methomyl was reversible, while the damage caused by equal to or greater than $200 \mu \mathrm{g} \cdot \mathrm{L}^{-1}$ methomyl was irreversible when tilapia were transferred to methomyl-free water for 18 days. Thus, a concentration of $200 \mu \mathrm{g} \cdot \mathrm{L}^{-1}$ could be used as a reference threshold for irreversible damage caused by methomyl in male tilapia.

Keywords: pesticide; freshwater fish; cholesterol; pregnenolone; progesterone; depuration period

\section{Introduction}

Methomyl $\left(\mathrm{C}_{5} \mathrm{H}_{10} \mathrm{~N}_{2} \mathrm{O}_{2} \mathrm{~S}\right)$ is a widely used carbamate pesticide that plays an important role in pest control and agricultural product harvest. Methomyl has been found in food crops and surface water due to its high solubility in water $\left(57.9 \mathrm{~g} \mathrm{~L}^{-1}\right.$ at $\left.25^{\circ} \mathrm{C}\right)$ and only weak or moderate adsorption in soil [1]. Methomyl residues in concentrations as high as $55.3 \mu \mathrm{g} \mathrm{L}^{-1}$ have been reported in natural water [2]. Because methomyl is often detected in natural water bodies and has the potential to disrupt the endocrine system in animals [3], its toxicity to aquatic animals has attracted extensive attention [4-7].

Recent evidence suggests that numerous compounds present in the environment act as hormone mimics and interfere with the reproductive status of vertebrates through effects ranging from alterations in plasma reproductive hormone levels to sterility [8]. An alteration in steroid hormone synthesis is an important biological response from a toxicological standpoint [9-11]. This is because the biological effects of pollutant exposure in organisms can be investigated through several molecular and biochemical biomarkers reflecting the onset of various cellular alterations [12,13]. These responses have been widely adopted as sensitive and reliable early warning signals for biological exposure to 
pollutants $[14,15]$. Therefore, this study aims to investigate the alterations in precursor molecules (cholesterol (CHO), pregnenolone (PREG), and progesterone (PROG)) in steroid hormone synthesis, concerning the methomyl dosage in the blood and testes of male tilapia (Oreochromis niloticus), to understand the toxic effects of methomyl on fish reproduction, and to protect the quality of natural water bodies.

\section{Materials and Methods}

\subsection{Fish and Chemicals}

Male Nile tilapia were obtained from a fish farm hatchery of Freshwater Fisheries Research Center of the Chinese Academy of Fishery Science (Wuxi, China), with an average weight of $112.24 \pm 9.48 \mathrm{~g}$ and an average length of $17.06 \pm 0.91 \mathrm{~cm}$. Tilapia were farmed in 200-L glass aquaria to acclimatize to the laboratory conditions for 4 weeks before the experiment. Dechlorinated tap water $\left(\mathrm{pH}: 7.0 \pm 0.5\right.$, temperature: $25 \pm 0.5{ }^{\circ} \mathrm{C}$, and dissolved oxygen: $6.3-7.0 \mathrm{mg} \mathrm{L}^{-1}$ ) was used in the experiment. A commercial feed purchased from Ningbo Tech-Bank Co., Ltd., China, was used to feed tilapia at a daily quantity of $2 \%$ of body weight. The photoperiod was 12-h light/12-h dark. Methomyl (CAS 16752-77-5) with a purity of $97 \%(w / w)$ was used. All other reagents were purchased from Sigma-Aldrich (St. Louis, MO, USA) or Sangon Biotech (Shanghai, China) and were of analytical grade.

\subsection{Experimental Design}

Thirty tilapia were randomly stocked in the glass aquaria with a volume of $300 \mathrm{~L}$, and the volume of test water was $200 \mathrm{~L}$. Fifteen glass aquaria were, in fact, used for the experiment. Five groups were set in the experiment. The nominal concentrations of methomyl were set as 0 (control), $0.2,2,20$, and $200 \mu \mathrm{g} \mathrm{L}^{-1}$, respectively, and each group had three replicates. The concentration of methomyl ranges was chosen according to the following information: the $96-\mathrm{h} \mathrm{LC}_{50}$ of methomyl to tilapia $\left(430 \mu \mathrm{g} \mathrm{L}^{-1}\right)$ from our previous research [7]; the residue levels of methomyl reported in the natural environmental water was in the range of $0-55.3 \mu \mathrm{g} \mathrm{L}^{-1}$ [2]; the maximum permissible concentration for methomyl in drinking water of $200 \mu \mathrm{g} \mathrm{L}^{-1}$ published by the United States Environmental Protection Agency (EPA) in 2012. Half of the water in the tank was changed daily, and methomyl was added as needed to maintain the nominal concentrations. The experiment lasted for 48 days, during which the tilapia were exposed to methomyl for 30 days and recovered in methomyl-free water for 18 days.

\subsection{Quantification of Methomyl}

An improved method called the ULTRA-performance liquid chromatography tandem mass spectrometry method was established to determine actual methomyl concentrations in the test water. The water samples in the 0 (control), $0.2,2,20$ and $200 \mu \mathrm{g} \mathrm{L}^{-1}$ groups were sampled, respectively, just after the fish were exposed and after exposure for $24 \mathrm{~h}$, with 3 replicates per treatment. The water sample was filtered through HLB column. Methomyl on the HLB column was eluted using methanol, and the eluted solution was concentrated to $1 \mathrm{~mL}$ by rotary evaporation and was then blown to dryness by nitrogen gas. Then, the residue was dissolved with acetonitrile and water $(v / v, 19: 1)$. The detection limits, standard addition recoveries, and RSD of methomyl were $0.063 \mu \mathrm{g} \mathrm{L}^{-1}, 87.9-109 \%$, and $3.6-8.5 \%$, respectively. The specified QA/QC procedures and methods are described in our previously published paper [16].

\subsection{Sampling and Biochemical Analysis}

Testes and serums ( $n=6$ per group) were sampled at $10 \mathrm{~min}$ (day 0 ) and on days 6,12 , 18,24 , and 30 in the methomyl exposure period (note: only the samples sampled at day 30 were used in this study) and at 18 days in the tilapia that recovered in methomyl-free water for 18 days. Tilapia were euthanized using $250 \mathrm{mg} \mathrm{L}^{-1} \mathrm{MS}-222$, and their length and weight were measured. Blood was collected from the caudal vein of the fish and then 
centrifuged at $1040 \times g$ for $15 \mathrm{~min}$ at $4{ }^{\circ} \mathrm{C}$. The separated serum samples were stored at $-80{ }^{\circ} \mathrm{C}$ for biochemical analysis. The testes were sampled immediately after sampling blood, snap-frozen using liquid nitrogen, and stored at $-80^{\circ} \mathrm{C}$ until analysis.

CHO, PREG, and PROG in the serum and testes of male tilapia were measured using ELISA kits following the manufacturer's protocols. The kits were purchased from Shanghai Zhaorui Biotechnology Co., LTD. Protein levels were estimated by the Bradford method [17] using bovine serum albumin as a standard. An electric homogenizer (PRO200; PRO Scientific Bio-Gen, Oxford, CT, USA), a refrigerated centrifuge (Sigma 2-16K, Osterode am Harz, Germany), and an ultraviolet-visible spectrophotometer (UV-Vis 759S, Shanghai, China) were used for homogenization, centrifugation, and quantification, of the samples, respectively.

\subsection{Statistical Analysis}

The levels of CHO, PREG, and PROG in the serum and testes of tilapia were compared with the levels in the controls for each sampling day; results were expressed as a percentage of the control. Statistical analyses were performed using SPSS 15.0. All data are expressed as the mean $\pm \mathrm{SD}(n=6)$, and significant differences were analyzed with one-way analysis of variance (ANOVA). Data were tested for normality of distribution (Shapiroe-Wilk test) and homogeneity of variance (Levene's test) prior to analysis. Data that did not meet assumptions of normality and homoscedasticity were transformed $(\mathrm{lg})$ and then analyzed by one-way ANOVA. Tukey's multiple comparisons and Student's $t$-test were used for statistical comparisons, with $p<0.05$ considered significant.

\section{Results}

The actual methomyl concentrations in the 0 (control), 0.2, 2, 20, and $200 \mu \mathrm{g} \mathrm{L}^{-1}$ groups were $0,0.23 \pm 0.02,2.12 \pm 0.13,21.50 \pm 1.21$, and $182.0 \pm 8.96 \mu \mathrm{g} \mathrm{L}^{-1}$, respectively, just after the fish were exposed and $0,0.21 \pm 0.03,1.92 \pm 0.14,18.52 \pm 1.43$, and $179.0 \pm 9.12 \mu \mathrm{g} \mathrm{L}^{-1}$, respectively, after exposure for $24 \mathrm{~h}$. The results are discussed in relation to the nominal concentrations.

The effects of chronic exposure to pesticide methomyl on sex steroid hormones $\mathrm{CHO}$, PREG, and PROG in the serum and testes of male tilapia and recovery patterns are shown in Figure 1. No significant changes $(p>0.05)$ were observed in the sex steroid hormones $\mathrm{CHO}$, PREG, and PROG in the serum and testes of male tilapia exposed to $0.2 \mu \mathrm{g} \mathrm{\textrm {L } ^ { - 1 }}$ and $2 \mu \mathrm{g} \mathrm{L}^{-1}$ methomyl, whereas male tilapia exposed to 20 or $200 \mu \mathrm{g} \mathrm{L}^{-1}$ methomyl showed significant changes $(p<0.05)$ : CHO, PREG, and PROG both in serum and testes were significantly decreased $(p<0.05)$. Moreover, dose-response relationships were found between methomyl and CHO, PREG, and PROG in both serum and testes. Specifically, CHO, PREG, and PROG, both in the serum and testes, decreased with an increase in methomyl concentration.

When the tilapia were transferred to methomyl-free water for 18 days, CHO, PREG, and PROG in both the serum and testes of male tilapia in each group recovered comparatively. There were no significant differences in CHO, PREG, and PROG both in the serum and testes of male tilapia exposed to 2 and $20 \mu \mathrm{g} \mathrm{L}^{-1}$ methomyl compared with the controls. Conversely, significant differences $(p<0.05)$ in the $200 \mu \mathrm{g} \mathrm{L}^{-1}$ treatment group were observed compared to the control group. 

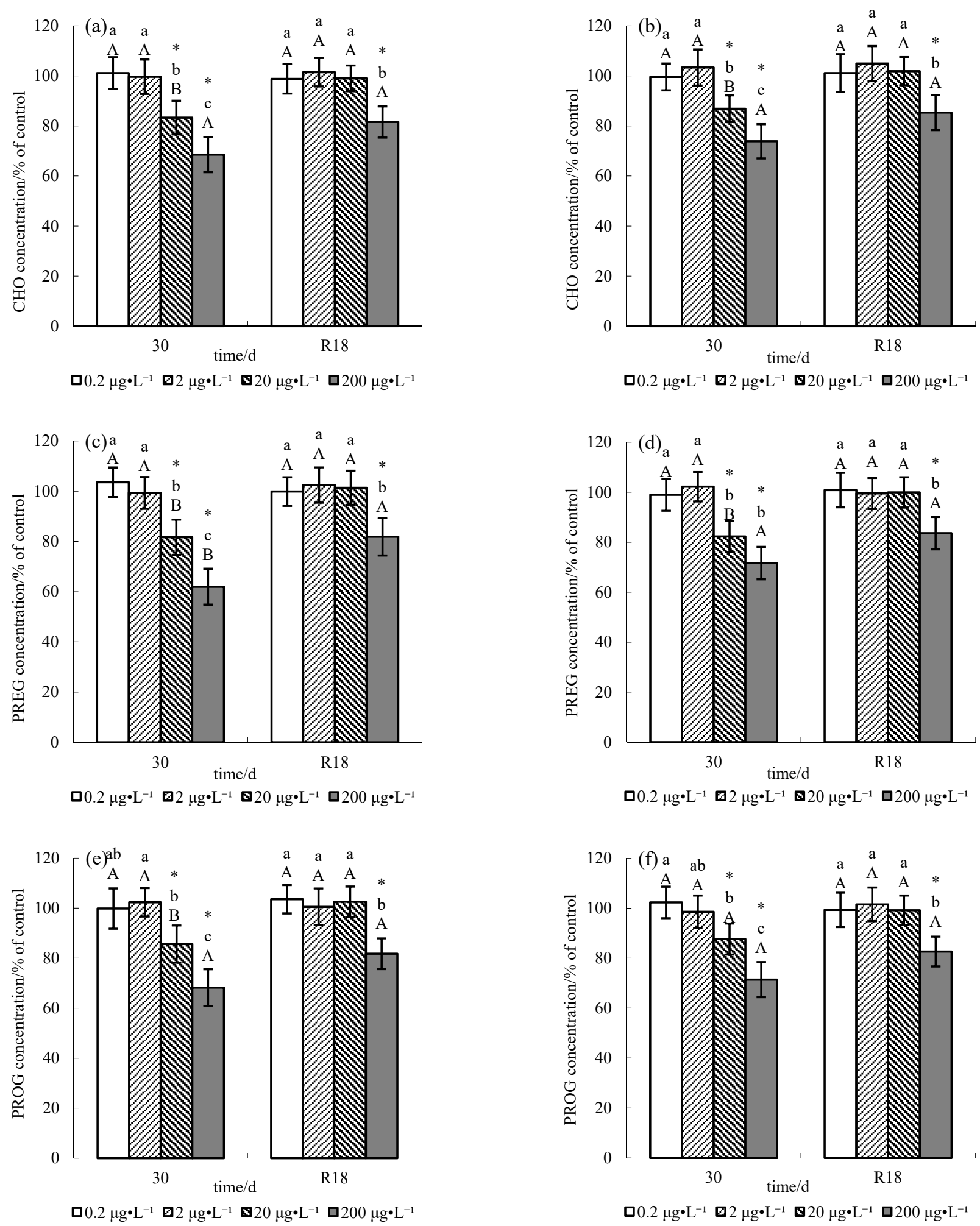

Figure 1. Cholesterol (CHO), pregnenolone (PREG), and progesterone (PROG) levels in testes (a,c,e) and serum (b,d,f) of male O. niloticus exposed to methomyl for 30 days and after an 18-day recovery period in methomyl-free water (R18). (Note: All the data were expressed as Average $\pm \operatorname{SD}(n=6)$. " " means significant difference from the control. Different lower-case letters indicate significant difference among concentrations at the same exposure period, and different upper-case letters indicate difference between exposure and recovery periods at the same methomyl concentration, with $p<0.05$ considered significant). 


\section{Discussion}

\subsection{Effect of Methomyl on Sex Steroid Hormone Synthesis Substrates}

$\mathrm{CHO}$ is a precursor of the sexual steroid hormones testosterone (T), 11-ketotestosterone (11-KT), and $17 \beta$-estradiol (E2). The basic process of CHO synthesis in fish is shown in Figure 2 [18]. $\mathrm{CHO}$ is transported from the mitochondrial outer membrane to the inner membrane under the action of steroidogenic acute regulatory protein (StAR) [19]. CHO is converted to PREG by the action of the CHO side-chain cleavage enzyme (CYP11A1) [20]. PREG is converted into PROG catalyzed by $3 \beta$-hydroxysteroid dehydrogenase (3 $\beta$-HSD) in the smooth endoplasmic reticulum [18], and $17 \alpha$ hydroxylase (P45017 $\alpha$ ) catalyzes the conversion of PREG and PROG to androgen [18]. Androgen is converted into estradiol under the catalysis of aromatase [21].

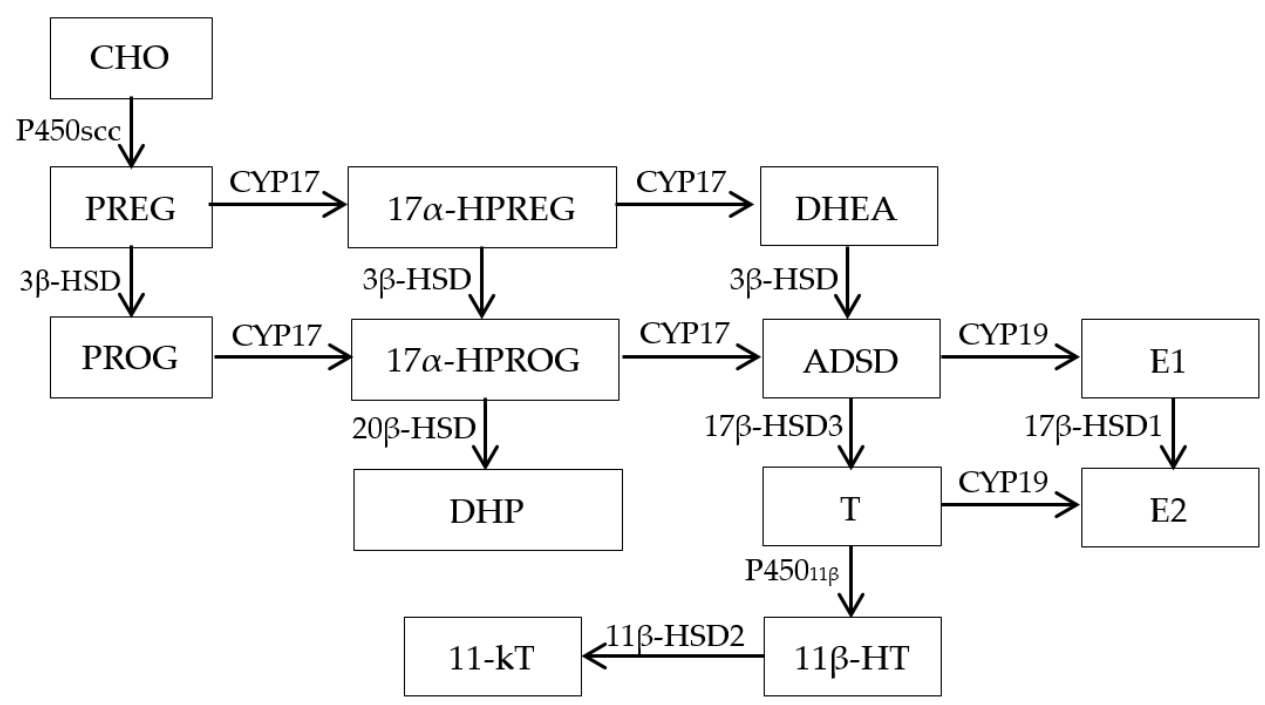

Figure 2. The sex hormone biosynthesis pathway in fish. (Note: CHO (Cholesterol), PREG (Pregnenolone), PROG (Progesterone), P450scc (Cholesterol side chain cleavage enzyme/CYP11A1), $3 \beta$-HSD (3 $\beta$-hydroxysteroid dehydrogenase), CYP17 (Cytochrome P450 17 $\alpha$-hydroxylase), $17 \alpha$ HPREG (17 $\alpha$-Hydroxypregnenolone), 17 $\alpha$-HPROG (17 $\alpha$-Hydroxyprogesterone), DHEA (Dehydroepiandrosterone), ADSD (Androstenedione), 17 $\beta$-HSD1 (17 $\beta$-hydroxysteroid dehydrogenase type I), 17 $\beta$-HSD2 (17 $\beta$-hydroxysteroid dehydrogenase type II), 17 $\beta$-HSD3 (17 $\beta$-hydroxysteroid dehydrogenase type III), E1 (Estrone), E2 (17 $\beta$-estradiol), T (Testosterone), 11-KT (11-ketotestosterone), $11 \beta$-HT (Hydroxytestosterone), DHP(17 $\alpha, 20 \beta$-dihydroxy Progesterone)).

In this study, methomyl had no significant effect on $\mathrm{CHO}$ content in serum and testes at low concentrations $\left(0.2\right.$ and $\left.2 \mu \mathrm{g} \mathrm{L}^{-1}\right)(p>0.05)$, but a significant $(p<0.05)$ decrease in $\mathrm{CHO}$ content in serum and testes at high methomyl concentrations $\left(20\right.$ and $\left.200 \mu \mathrm{g} \cdot \mathrm{L}^{-1}\right)$ was found. Mu et al. [22] studied the effect of difenoconazole on $\mathrm{CHO}$ in zebrafish and found that low concentrations of difenoconazole $\left(0.1 \%\right.$ and $\left.10 \mu \mathrm{g} \mathrm{L}^{-1}\right)$ had no significant effect on $\mathrm{CHO}$ content $(p>0.05)$. High concentrations $\left(500 \mu \mathrm{g} \mathrm{L}^{-1}\right)$ significantly reduced $\mathrm{CHO}$ content $(p<0.05)$, which was consistent with the change trends of $\mathrm{CHO}$ in our study. Other studies have also shown that environmental estrogen could alter gonadal steroid production at specific sites within the steroidogenic pathway, that is, downstream of $\mathrm{CHO}$ mobilization to side-chain cleavage of P450scc and/or conversion of CHO to PREG [23]. The decreased levels of PREG produced by the testes of methomyl-treated tilapia suggest that methomyl may affect $\mathrm{CHO}$ availability or reduce the activity of the side-chain cleavage enzyme P450scc, which mediates the conversion of CHO to PREG [8].

Similarly, the response of PREG and PROG to methomyl in serum and testes showed no effect at low concentrations $\left(0.2\right.$ and $\left.2 \mu \mathrm{g} \mathrm{L}{ }^{-1}\right)(p>0.05)$ and significantly decreased at high concentrations $\left(20\right.$ and $\left.200 \mu \mathrm{g} \mathrm{L}^{-1}\right)$. However, a significant $(p<0.05)$ decrease in the present experiment, consistent with that of $\mathrm{CHO}$ in the serum and testes, was ob- 
served. PREG is transformed from CHO under the catalysis of CYP11A1 [20], and PROG is transformed from PREG under the catalysis of $3 \beta-H S D$ in the smooth endoplasmic reticulum [18]. Therefore, a decrease in CHO content inevitably leads to a decrease in PREG and PROG content. At the same time, our previous study showed that the expression of testes $3 \beta$-HSD mRNA was significantly inhibited at high concentrations $\left(20\right.$ and $\left.200 \mu \mathrm{g} \mathrm{L}^{-1}\right)$ $(p<0.05)$, and the inhibition intensity increased with an increase in methomyl concentration [5]. This suggests that decreased levels of $3 \beta-H S D$ in the testes further inhibited the conversion of PREG to PROG, thereby exacerbating the decline in PROG levels.

The liver is the main site of CHO synthesis in the body, as well as an important organ to maintain $\mathrm{CHO}$ demand and the stability of blood $\mathrm{CHO}$ content [24]. Therefore, the significant decrease in serum $\mathrm{CHO}$ content in this study indicates that its synthesis in the liver is blocked to some extent. Meanwhile, $\mathrm{CHO}$, which is used as a steroid hormone synthesis substrate in teleost fish, is mainly exogenous CHO absorbed from plasma [25]. Under the action of lipoproteins, $\mathrm{CHO}$ is transported from the synthesis or absorption site to the functional site through blood circulation. The sex hormone synthesis pathway is initiated only when $\mathrm{CHO}$ is transported into the inner membrane of mitochondria [18]. Transmembrane transport of $\mathrm{CHO}$ from the mitochondrial outer membrane to the intima is a rate-limiting step in sex hormone synthesis [26]. The CHO transport process in fish is completed by high-density lipoprotein (HDL) [27], and StAR is an important CHO transporter involved in $\mathrm{CHO}$ metabolism. Therefore, damage to the StAR protein could lead to obstruction of the CHO transport pathway [18]. The simultaneous study of our experiment showed that methomyl had no significant $(p>0.05)$ effect on the expression of StAR mRNA in the testes at low concentrations $\left(0.2\right.$ and $\left.2 \mu \mathrm{g} \mathrm{L}^{-1}\right)$ but significantly $(p<0.05)$ inhibited its expression at high concentrations $\left(20\right.$ and $\left.200 \mu \mathrm{g} \mathrm{L}^{-1}\right)$ [5]. Consequently, the decreased $\mathrm{CHO}$ content in the testes induced by methomyl at high concentrations (20 and $200 \mu \mathrm{g} \mathrm{L}^{-1}$ ) was due to both the obstruction of $\mathrm{CHO}$ synthesis and transport pathways. CHO, PREG, and PROG are the primary precursors of sex steroid hormones. The synthesis of steroid hormones and their primary precursors is an important and critical factor in the physiological development of organisms, including growth, development, and reproduction [28]. Therefore, the decrease in CHO, PREG and PROG levels affects the synthesis of sex steroid hormones and ultimately affects the reproductive development of fish [18].

\subsection{Recovery Pattern}

Recovery tests showed that the levels of CHO, PREG, and PROG in the serum and testes of tilapia exposed to 2 and $20 \mu \mathrm{g} \mathrm{L}^{-1}$ methomyl recovered when tilapia were transferred to methomyl-free water for 18 days. However, the degree of recovery differed for different methomyl concentrations. The above parameters in the $20 \mu \mathrm{g} \mathrm{L}^{-1}$ recovery group were not significantly different than those in the control group $(p>0.05)$, and all of them returned to normal levels. However, in the $200 \mu \mathrm{g} \mathrm{L}^{-1}$ recovery group, their levels still significantly differed from those in the control group $(p<0.05)$ and were not restored to normal levels after 18 days. In conclusion, the damage to male tilapia steroid synthetic substrates caused by $\leq 20 \mu \mathrm{g} \mathrm{L}^{-1}$ methomyl could be recovered, while that caused by $\geq 200 \mu \mathrm{g} \mathrm{L}^{-1}$ methomyl could not be recovered within 18 days. Hence, $200 \mu \mathrm{g} \mathrm{L}^{-1}$ can be used as the reference threshold value for irreversible damage caused by methomyl in male tilapia.

\section{Conclusions}

Methomyl exposure at low concentrations $\left(0.2\right.$ and $\left.2 \mu \mathrm{g} \mathrm{L}^{-1}\right)$ had no significant effects on the contents of cholesterol (CHO), pregnenolone (PREG), and progesterone (PROG) in the serum and testes of male tilapia $(p>0.05)$. An amount of $2 \mu \mathrm{g} \mathrm{L}^{-1}$ can be preliminarily used as the reference threshold value of a "no-effect dose" of methomyl in male tilapia.

Methomyl at high concentrations (20 and $\left.200 \mu \mathrm{g} \mathrm{L}^{-1}\right)$ significantly inhibited the contents of cholesterol ( $\mathrm{CHO})$, pregnenolone (PREG), and progesterone (PROG) in the 
serum and testes of male tilapia $(p<0.05)$ and showed a dose-response relationship. Since cholesterol is a synthetic substrate for sex steroid hormones, a decrease in cholesterol levels can affect the synthesis of sex steroid hormones, which, in turn, affects the reproductive function of tilapia.

The damage of steroid synthetic substrates in male tilapia caused by the lower methomyl levels of $20 \mu \mathrm{g} \mathrm{L}{ }^{-1}$ was reversible within 18 days after exposure, but the damage caused by $200 \mu \mathrm{g} \mathrm{L}^{-1}$ methomyl was irreversible.

Author Contributions: Conceptualization, S.M. and X.C.; methodology, C.S.; software, L.F.; validation, J.C., P.X. and S.M.; formal analysis, L.Q. and G.H.; resources, J.C.; data curation, X.C.; writing-original draft preparation, S.M.; writing-review and editing, X.C.; visualization, S.M.; supervision, J.C. and P.X.; project administration, J.C.; funding acquisition, J.C. All authors have read and agreed to the published version of the manuscript.

Funding: This research was funded by the China Agriculture Research System of MOF and MARA (No.CARS-46) and the National Key Research and Development Program of China (No.2020YFD0900502).

Institutional Review Board Statement: Not applicable.

Informed Consent Statement: Not applicable.

Data Availability Statement: The datasets analyzed during the current study are available from the corresponding author upon reasonable request.

Conflicts of Interest: The authors declare no conflict of interest.

Ethic Statement: This study was approved by the Ethics Committee of the Freshwater Fisheries Research Center, Chinese Academy of Fishery Sciences (Institutional Animal Care and Ethics Committee of Nanjing Agricultural University, Nanjing, China. [Permit number: SYXK (Su) 2011-0036]).

\section{References}

1. Kongphonprom, K.; Burakham, R. Determination of carbamate insecticides in water, fruit, and vegetables by ultrasound-assisted dispersive liquid-liquid micro extraction and high-performance liquid chromatography. Anal. Lett. 2016, 49, 753-767. [CrossRef]

2. Van Scoy, A.R.; Yue, M.; Deng, X.; Tjeerdema, R.S. Environmental fate and toxicology of methomyl. Rev. Environ. Contam. T 2013, 222, 93-109.

3. Guo, X.B. Environmental Health; Peking University Medical Press: Beijing, China, 2006.

4. Meng, S.L.; Hu, G.D.; Qiu, L.P.; Song, C.; Fan, L.M.; Chen, J.Z.; Xu, P. Effects of chronic exposure of methomyl on the antioxidant system in kidney of tilapia (Oreochromis niloticus) and recovery pattern. J. Toxicol. Environ. Health A 2013, 76, 937-943. [CrossRef]

5. Meng, S.L.; Qiu, L.P.; Hu, G.D.; Fan, L.M.; Song, C.; Zheng, Y.; Wu, W.; Qu, J.H.; Li, D.D.; Chen, J.Z.; et al. Effects of methomyl on steroidogenic gene transcription of the hypothalamic-pituitary-gonad-liver axis in male tilapia. Chemosphere 2016, 165, 152-162. [CrossRef] [PubMed]

6. Meng, S.L.; Qiu, L.P.; Hu, G.D.; Fan, L.M.; Song, C.; Zheng, Y.; Wu, W.; Qu, J.H.; Li, D.D.; Chen, J.Z.; et al. Effect of methomyl on sex steroid hormone and vitellogenin levels in serum of male tilapia (Oreochromis niloticus) and recovery pattern. Environ. Toxicol. 2017, 32, 1869-1877. [CrossRef]

7. Meng, S.L.; Chen, X.; Song, C.; Fan, L.M.; Qiu, L.P.; Zheng, Y.; Chen, J.Z.; Xu, P. Effect of chronic exposure to pesticide methomyl on antioxidant defense system in testis of tilapia (Oreochromis niloticus) and its recovery pattern. Appl. Sci. 2021, 11, 3332. [CrossRef]

8. Maclatchy, D.L.; Vanderkraak, G.J. The phytoestrogen $\beta$-sitosterol alters the reproductive endocrine status of goldfishsciencedirect. Toxicol. Appl. Pharmacol. 1995, 134, 305-312. [CrossRef]

9. Ibor, O.R.; Adeogun, A.O.; Chukwuka, A.V.; Arukwe, A. Gross pathology, physiological and toxicological responses in relation to metals and persistent organic pollutants (POPs) burden in tilapia species from ogun river, nigeria. Mar. Environ. Res. 2017, 129, 245-257. [CrossRef]

10. Choi, J.; Lee, G.; Kim, S.; Choi, K. Investigation on sex hormone-disruption effects of two novel brominated flame retardants (DBDPE and BTBPE) in male zebrafish (Danio rerio) and two human cell lines (H295R and MVLN). Appl. Sci. 2021, 11, 3837. [CrossRef]

11. Ferreira, C.; Oliveira, M.; Santos, M.A.; Pacheco, M. Effects of benzo[a]pyrene, cortisol, and 17-estradiol on liver microsomal erod activity of Anguilla anguilla: An In Vitro approach. Appl. Sci. 2021, 11, 2533. [CrossRef]

12. Osman, A.G.M.; Reheem, A.E.; AbuelFadl, K.Y.; Gad El-Rab, A.G. Enzymatic and histopathologic biomarkers as indicators of aquatic pollution in fishes. Nat. Sci. 2010, 2, 1302-1311. [CrossRef]

13. Pereira, S.; Pinto, A.L.; Cortes, R.; Fontainhas-Fernandes, A.; Coimbra, A.M.; Monteiro, S.M. Gill histopathological and oxidative stress evaluation in native fish captured in Portuguese Northwestern Rivers. Ecotoxicol. Environ. Saf. 2013, 90, 157-166. [CrossRef] 
14. Regoli, F.; Giuliani, M.E.; Benedetti, M.; Arukwe, A. Molecular and biochemical biomarkers in environmental monitoring: A comparison of biotransformation and antioxidant defense systems in multiple tissues. Aquat. Toxicol. 2011, 105, 56-66. [CrossRef] [PubMed]

15. Regoli, F.; Giuliani, M.E. Oxidative pathways of chemical toxicity and oxidative stress biomarkers in marine organisms. Mar. Environ. Res. 2014, 93, 106-117. [CrossRef]

16. Meng, S.L.; Liu, T.; Song, C.; Zhang, C.; Qiu, L.P.; Chen, J.Z.; Xu, P. Determination of Methomyl Residue in Water by Ultra Performance Liquid Chromatography-Tandem Mass Spectrometry. J. Anhui Agric. Sci. 2018, 46, 166-167.

17. Bradford, M.M. A rapid and sensitive method for the quantitation of microgram quantities of protein utilizing the principle of protein-dye binding. Anal. Biochem. 1976, 72, 248-254. [CrossRef]

18. Wang, H. Effects and Mechanisms of Monocrotophos Pesticide on Sex Hormone Synthesis and Transformation in the Male Goldfish (Carassius auratus); Ocean University of China: Qingdao, China, 2013.

19. Thongbuakaew, T.; Suwansa-Ard, S.; Chaiyamoon, A.; Cummins, S.F.; Sobhon, P. Sex steroids and steroidogenesis-related genes in the sea cucumber, holothuria scabra and their potential role in gonad maturation. Sci. Rep. 2021, 11, 2194. [CrossRef]

20. Zhang, Y.H.; Li, X. Research progress in steroidogenic acute regulatory protein. J. Shanxi Norm. Univ. Nat. Sci. Ed. 2009, 37, 85-89.

21. Barannikova, I.A.; Bayunova, L.V.; Semenkova, T.B. Serum levels of testosterone, 11-ketotestosterone and oestradiol-17 $\beta$ in three species of sturgeon during gonadal development and final maturation induced by hormonal treatment. J. Fish. Biol. 2004, 64, 1330-1338. [CrossRef]

22. Mu, X.Y. The Toxicity Effect and Mechanism of Difenoconazole on Zebrafish (Danio rerio); Agricultural University: Beijing, China, 2015.

23. Hogan, N.S.; Currie, S.; Le Blanc, S.; Hewitt, M.L.; MacLatchy, D.L. Modulation of steroidogenesis and estrogen signalling in the estuarine killifish (Fundulus heteroclitus) exposed to ethinylestradiol. Aquat. Toxicol. 2010, 98, 148-156. [CrossRef]

24. Meng, X.X.; Wei, Y.L.; Liang, M.Q.; Xu, H.G. Progress in Cholesterol Nutritional Requirements of Fish. Chin. J. Anim. Nutr. 2021, 33, 719-728.

25. Sharpe, R.L.; Woodhouse, A.; Moon, T.W.; Trudeau, V.L.; MacLacthy, D.L. $\beta$-Sitosterol and $17 \beta$-estradiol alter gonadal steroidogenic acute regulatory protein (StAR) expression in goldfish, Carassius auratus. Gen. Comp. Edocr. 2007, 151, 34-41. [CrossRef] [PubMed]

26. Jefcoate, C.R.; McNamara, B.C.; Artemenko, I.; Yamazaki, T. Regulation of cholesterol movement to mitochondrial cytochrome P450scc in steroid hormone synthesis. J. Steroid. Biochem. Mol. Biol. 1992, 43, 751-767. [CrossRef]

27. Babin, P.J.; Vernier, J.M. Plasma lipoproteins in fish. J. Lipid Res. 1989, 30, 467-489. [CrossRef]

28. Sayed, A.D.; Mahmoud, U.M.; Mekkawy, I.A. eproductive biomarkers to identify endocrine disruption in Clarias gariepinus exposed to 4-nonylphenol. Ecotoxicol. Environ. Saf. 2012, 78, 310-319. [CrossRef] [PubMed] 